Article

\title{
Does Seeing "Mind Acts Upon Mind" Affect Green Psychological Climate and Green Product Development Performance? The Role of Matching Between Green Transformational Leadership and Individual Green Values
}

\author{
Shunyi Zhou ${ }^{1}$, Dapeng Zhang ${ }^{1, *} \mathbb{1}$, Chan Lyu ${ }^{2, *}$ and Hongfeng Zhang ${ }^{3}$ \\ 1 School of Business Administration, Northeastern University, Shenyang 110169, China; \\ syzhou@stumail.neu.edu.cn \\ 2 School of Business, Macau University of Science and Technology, Taipa 999078, Macau \\ 3 Management Board Office, Macao Polytechnic Institute, Macau 999078, Macau; hfengzhang@ipm.edu.mo \\ * Correspondence: 1610411@stu.neu.edu.cn (D.Z.); chlyu@must.edu.mo (C.L.)
}

Received: 24 July 2018; Accepted: 28 August 2018; Published: 7 September 2018

check for updates

\begin{abstract}
In the field of management psychology, the matching of employees and leaders can help improve enterprise performance. Then, in the field of sustainable development, can human aspects enhance green product development performance? Does the match between leaders and employees help to advance this improvement? A survey questionnaire was used to collect data for this study; 52 leaders and their 214 employees were contacted. The findings of this study revealed that green transformational leadership is positively related to green product development performance. Besides, both green transformational leadership and individual green values have positive influences on green psychological climate, which leads to the promotion of green product development performance in the organization. Further, when green transformational leadership matches employees with green values, it is more conducive to create green psychological climate in the organization, thereby improving the green products development performance. The implications for practitioners are discussed on the basis of the empirical findings.
\end{abstract}

Keywords: green transformational leadership; green product development performance; individual green values; green psychological climate; person-supervisor fit theory

\section{Introduction}

Population growth, industrial production, and non-renewable resources have negatively impacted the environment [1,2]. The environment control of the government [3] and the strong demands for environmental standards from consumers [4] and other stakeholders [5] have increased gradually, creating challenges for enterprises' original one-sided pursuit of profit maximization. The inevitable trend of sustainable development is urging enterprises to carry out reforms in order to seek a balance between the development of the corporation and the natural environment. Some scholars introduced a new concept called green products $[3,6]$. Chen and Chang stated that green products can help realize the balance between the development of enterprises and the natural environment [6]. They defined green products as those that are less harmful to the environment, are formed or partly formed from recycled components, are manufactured with a focus on energy conservation, or are supplied to the market with less packaging [6]. Companies realize that green products have become a powerful competitive tool in the market [3]. Various of studies have shown that consumers realize the seriousness of this problem and have started boycotting non-green products due to the changes in global temperature 
and climate $[7,8]$. In the environmental era, consumers are more willing to take part in environmental protection business activities [9]. Over time, they have become increasingly willing to buy green products [3]. Therefore, companies must reform their business models and produce environmentally friendly green products.

When green products are more popular in the market, green product development becomes more prevalent $[6,10]$. Different than traditional product development, green products more extensively consider environmental impacts by focusing on the life cycle of the product, mining the subsequent use of the products and recognizing the social environment of the whole product supply chain [11]. Green product development plays an important role in determining the sales of green products. This development process not only changes company management models, but also reshapes market rules [12]. However, many companies remain stuck in the stage of recognizing the product management model as "pollution-governance". They neglect the fact that the reform of companies requires a new kind of leadership-green transformational leadership. Although some studies have found that green transformational leadership has a significantly positive impact on green product development performance [6], the role of leaders was mainly discussed. In fact, prior literature has widely identified that the performance of companies is due to the interactive relations between leaders and their employees [13]. For instance, Kim et al. found that transformational leadership could facilitate the linkage between employee core self-evaluation and employee outcomes [14]. Therefore, in this study, we aimed to fill the research gap by analyzing the effects of green transformational leadership and individual green values. Moreover, a recent study from Jabbour et al. examined 62 Brazilian companies and found that the relations between human and organizational aspects to green product development was not significant [9]. However, prior studies have shown that human aspects like sustainable organizational climate [15] and employee dedication [16] could support environmental management. Thus, this study would like to further explore this problem.

This study proposes four novel constructs: green transformational leadership, green psychological climate, green product development, and individual green values. Based on these constructs, we tried to emphasize the matching relationship between green transformational leadership and employee individual green values based on person-supervisor fit theory, to determine their influence on green product development performance through the green psychological climate. As the concept of individual green values is not well-described in the existing literature, this study first proposes a clear definition of this construct. Then, we explore the impact of human aspects on green product development performance to verify how green transformational leadership and individual green values affect green psychological climate and green product development performance. Next, we discuss the interaction between leaders and employees to verify whether the matching effect between individual green values and green transformational leadership further improves green product development performance. Finally, this study concludes with theoretical and practical implications for future research.

\section{Literature Review and Hypotheses Formulation}

\subsection{Green Transformational Leadership and Green Product Development Performance}

\subsubsection{Green Transformational Leadership}

Based on the resource-based viewpoint, leadership is one of the important internal resources and capabilities in enterprise environmental management $[17,18]$. Previous literature has widely demonstrated that transformational leadership has a direct and unique impact on creating an innovative atmosphere by encouraging team members, which ultimately affects the performance of enterprises [19-22]. Green transformational leadership is the product of transformational leadership in the field of environmental protection. It was first proposed by Chen and Chang [6] with reference to transformational leadership concept introduced by Bass [23]. They defined green transformational 
leadership as "behaviors of leaders who motivate followers to achieve environmental goals and inspire followers to perform beyond expected levels of environmental performance" [24].

According to culturally endorsed transformational leadership theories discussed by Muralidharan and Pathak, different degrees of cultural endorsement can lead to different kinds of transformational leadership [25]. Since the idea of green transformational leadership is consistent with the need for social green development, it can also be seen as a kind of culturally endorsed transformational leadership.

\subsubsection{Green Product Development Performance}

As green development has become increasingly prevalent, companies still struggle to determine how to generate profits from green products [26]. As a kind of innovative model for a company, green product development needs to break the original production mode [27]. Chen and Chang first proposed the novel notion of "Green product development performance" to describe the related outcomes [6]. They defined it as:

the development performance of products that have less of an impact on the environment, are less detrimental to human health, are formed or part-formed from recycled components, are manufactured in a more energy-conservative way, or are supplied to the market with less packaging.

\subsubsection{Relationship Between the Above Two Concepts}

The influence of transformational leadership on an organization's sustainable development has already become a hot topic. Many findings revealed that transformational leadership has a significant positive impact on organizational sustainable development $[28,29]$. Green transformational leadership, as one kind of culturally endorsed transformational leadership, can help formulate green development strategies and push enterprises toward the goal of green development [30]. Therefore, we hypothesized that green transformational leadership will positively promote the green product development performance, for the following reasons. First, transformational leadership is beneficial for the development of new ideals in the problem-solving process because transformational leaders can act as catalysts by inspiring followers to consider problems from a different perspective [30]. When green product development is involved in problems like energy conservation and pollution-preventions [6], with the encouragement of green transformational leadership, employees can actively engage in green product development processes [30]. Studies have already shown that employee engagement contributes to enhancing product development performance [31]. Besides, transformational leadership can provide resource support to employees. They provide technological support [9] and stimulate employees' creativity $[6,18]$. Technology and innovation are two important factors in the development of new products [32]. Previous studies indicated that employee innovation positively influences green product development [30], and technological factors also play significant roles in stimulating green product development performance [9]. Therefore, according to the above statement, we introduce our first hypothesis:

Hypothesis 1 (H1). Green transformational leadership is positively related to green product development performance.

\subsection{Mediating Role of Green Psychological Climate}

\subsubsection{Green Psychological Climate}

In the field of management psychology, organizational climate is considered an important contextual factor that reflect employees' attitudes and behaviors [33-35]. If employees share similar perceptions of formal policies, company targets, and work environment, then the employees' everyday practices will work toward the vision of the enterprise [34]. Based on organizational climate, Norton et al. introduced the concept of green psychological climate [36]. They defined it as employees' 
perceptions and interpretations of their organization's policies, procedures, and practices regarding environmental sustainability.

\subsubsection{Transformational Leadership and Green Psychological Climate}

The leadership literature suggests that transformational leadership influences organizational performance by its effect on employees' psychological climate $[28,37]$. Thus, employee perception and interpretation of organizational policies, procedures that translate policies into guidelines, and practices expected and rewarded by the organization, are highly dependent upon transformational leaders. As stated by Zhang et al., the leader can shape the supportive climate in an organization [38]. At the organizational level, a recent study showed that corporate environmental strategy could positively affect green psychological climate [36]. As the creator of organizational strategy, green transformational leadership also has an important impact on green psychological climate. Green transformational leaders set a vision of green development for the organization [30], in which employees feel motivated when engaging in corresponding work. From the perspective of social influence theory [39], engagement and psychology are further exchanged between leaders and employees, which ultimately creates a strong psychological climate in the company. At the individual level, green transformational leadership has a positive effect on individual green organizational identity [3]. The organizational identity enhances employee's sense of wellbeing and belonging [40,41], which in turn urges the employee to generate organizational citizenship behavior [28] to take the initiative to care about the organization's policies, procedures, and practices regarding environmental sustainability [36]. In summary, we expected that a green transformational leader has a positive effect on green psychological climate.

Hypothesis 2 (H2). Green transformational leadership is positively related to green psychological climate.

\subsubsection{Green Psychological Climate and Green Product Development Performance}

Employee psychological climate plays a key role in producing high organizational performance $[42,43]$. Some studies demonstrated that the main factor causing delays in organizational environmental improvement is how to create a sustainable organizational climate [44-46]. First of all, if employees are not responsible for the use of the company's energy and facilities, it is difficult for them to invest in green behaviors [47]. As such, green behaviors can be seen as extra-role behaviors. However, if an organization creates a strong psychological climate, then this conveys to employees not only that green behaviors are safe, but also urges them to take responsibility to engage in green works and view green behaviors as in-role behaviors. As studied by Dumont et al., green psychological climate can both positively influence employees' extra-role green behavior and in-role green behavior [48]. Second, Norton et al. demonstrated that when employees perceive a positive green psychological climate, the relationship between behavioral intentions and next-day employee green behaviors is stronger [36]. Based on the above logic, as pointed by Day and Bedeian, employees' green behaviors can be used to predict their work engagement and performance [49]. They confirmed that organizational psychological climate is beneficial for predicting employees' work engagement and performance [47]. Specifically, when employees are concerned about environmental issues in the company, they are more likely to engage in green product development work. Their organizational commitment related to organization green product development increases [50], which helps to increase green product development performance. Moreover, according to person-supervisor fit theory, when leaders and employees see that "mind acts upon mind" in the organization, it can create a strong organizational climate, which is conducive to the improvement of corporate performance [51]. In conclusion, we expected that green psychological climate is positively related to green product development performance, and posit the following hypothesis:

Hypothesis 3 (H3). Green psychological climate is positively related to green product development performance. 
In the field of human resource management, scholars have strong interest in the link between different leadership styles and organizational performance [52]. For instance, an organizational climate could be developed and established by transformational leaders who encourage employees to achieve high performance [53]. A supportive climate can be served as a key mediator for organizational performance [38]. Therefore, in the field of sustainable development, based on H1, H2, and H3, this paper proposes that green transformational leadership has a positive effect on green product development performance through green psychological climate and posits the following hypothesis:

Hypothesis 4 (H4). Green psychological climate mediates the relationship between green transformational leadership and green product development performance.

\subsection{Individual Green Values and Green Product Development Performance}

\subsubsection{Individual Green Values}

Contemporary literature has underscored the importance of individual values on explaining individual attitudes and behaviors [54]. Green values are the product of sustainable development, which mainly refers to individual attitudes and behaviors in sustainable development [48]. However, scholars have not yet reached a consensus on the concept of individual green values. Dunlap and Van Liere defined the New Environmental Paradigm (NEP) to conceptualize beliefs about humanity's ability to upset the balance of nature, the existence of limits to growth for human societies, and humanity's right to rule over the rest of nature [55]. However, Stern et al. stated that Dunlap and Van Liere failed to ground the NEP in social-psychological theories of attitude structure [56]. Therefore, Dunlap et al. developed the "environmental belief" to describe and measure people's beliefs and values in environmental concerns [57]. Dumont et al. thought that value-belief-norm theory and supplies-values fit theory could underpin the ways in which individuals' values affect their behavior by adopting the "environmental norms" from Chou to measure individual green values [48]. However, Chou integrated the theory of norm-activation (TNA) and NEP from the value-belief-norm theory [58], and argued that both environmental beliefs and environmental norms are factors explaining the process of environmental behavior activation [59]. Environmental beliefs regarding the ecological worldview, as held by NEP (e.g., "If things continue on their present course, we will soon experience a major ecological catastrophe"), then lead to environmental norms, which determine how people intend to act in face of these environmental problems held by the TNA. Based on the study of Chou, this study argues that integrating these two factors can better reflect employee individual green values.

\subsubsection{Relationship Between Individual Green Values and Green Product Development Performance}

Person-supervisor fit theory grew from person-environment fit theory, which indicates that when individuals' values are fit with the environment, including the supervisor, the group, and the organization, the values help stimulate outcomes, such as performance and employee behavior [51]. Thus, we propose that individual green values have positive effects on green product development performance. The reasons are as follows. First of all, employees with environmental beliefs pay more attention to the attractiveness of the work itself and seek a work environment that matches the self-internal preferences. Therefore, for their internal preference [60,61], employees with green values will take the initiative to seek a company with green development concepts and perform better in this company where that provides more self-satisfaction and is more suitable for themselves. Second, individuals with green values pay attention to environmental problems and take social responsibility into consideration. Due to self-verification [62], if employees' self-values and behaviors are not consistent, the individuals will feel anxiety and uncertainty [18]. Therefore, in order to maintain their self-values and perform behaviors that are consistent, individuals will have green behaviors and strive to create better work performance, which is beneficial for green product development. Third, employees care about their long-term career development. If they perceive the organizational 
development goal is to strive to improve green product development performance, employees with green values are bound to do their own job well [63]. Finally, some studies showed that individual values are related to emotions [64]. As the green values meet the needs of social development today [27], employees are more likely to maintain positive emotions. As such, employees will actively accomplish various green product development tasks, and contribute to the improvement of organizational green product development performance. Based on the above analysis, this paper posits the following hypothesis:

Hypothesis 5 (H5). Individual green values are positively related to green product development performance.

\subsection{Relationship Between Individual Green Values and Green Psychological Climate}

In the field of management psychology, individual values significantly influence individual psychology [65]. Moreover, according to person-supervisor fit theory, if the values of the supervisor are congruent with those of the employee, through the interactions between leaders and employees, and the interactions amongst employees, they are more likely to create a strong psychological climate $[51,66]$. Therefore, this paper proposes that individual green values are positively related to green psychological climate. The reasons are as follows. First, according to social influence theory, employees and leaders influence each other and create a consistent, high-intensity organizational atmosphere in the organization [39]. Therefore, when most employees in the organization have green values, individuals share their attitudes and opinions in the process of understanding and interpreting the organizational environment, which forms signs like minority obedience to the majority and group thinking. This leads to the formation of a high-intensity green psychological climate. Second, Kozlowski and Klein posited that individual-level values would be amplified through interaction and appear as a higher-level common structure [67]. As such, individual green values, through the interaction of peers and upper and lower levels of communication are magnified and create the green psychological climate on the team-level and even the organizational-level [67]. Third, Schneider pointed out that individuals with similar characteristics would be attracted to the same team or organization, then choose to enter and stay in this team or organization due to the principle of Attraction-Selection-Attrition [68]. Over time, this team or organization would be composed of individuals with similar backgrounds, interests, cognitions, and values, and lead to homogenization [69]. As the degree of homogenization increases, individuals may expect to perceive the work environment in a similar way. That is, members in the same organization or team will have similar perceptions of the environment and eventually form a strong psychological climate in the team. Based on the above analysis, this paper proposes the following hypothesis:

Hypothesis 6 (H6). Individual green values are positively related to green psychological climate.

Based on the above hypothesis, individual green values are positively related to green product development performance. In addition, individual green values are positively related to green psychological climate, and green psychological climate is positively related to green product development. Thus, individual green values are positively related to green product development performance through the green psychological climate. We introduce the following hypothesis:

Hypothesis 7 (H7). Individual green values mediate the relationship between individual green values and green product development performance.

\subsection{Matching Role Between Individual Green Values and Green Transformational Leadership}

A study conducted by Dumont et al. proved that individual green values positively moderate the effect of psychological green climate on extra-role green behavior [48]. However, they used supplies-values fit theory $[70,71]$ to explore employees' psychological climate and values 
through their behaviors. Conversely, this study emphasizes the matching relationship between leaders and employees to explore their influence on employee psychology. One major theory is the person-supervisor fit theory [50]. The studies of leader-follower value congruence [72], supervisor-subordinate personality similarity [73], and manager-employee goal congruence [74] are all included in this category. It largely underpins the matching relationship between supervisors and subordinates, that is, "mind acts upon mind" between employees and their leaders. The person-supervisor fit theory posits that when supervisors' psychological characteristics and values fit with those of employees, it leads to a positive relationship between their psychology and behavior [66]. Moreover, according to Muralidharan and Pathak, if the leadership style is consistent with the social culture, employees with the same values will recognize and strive to fulfill leaders' and organizations' expectations [27]. Therefore, the match between leaders and employees plays an important role in achieving organizational goals and helps employees perceive organizational policies. We expected that employees would be more likely to enhance their green psychological climate, which leads to high green product development performance when their values, personality, and goals are congruent to their leaders.

Individual green values includes environmental beliefs [57] and environmental norms [48,58]. Environmental beliefs influence employees to be environmentally conscious and pay attention to environmental issues in the production process. Environmental norms mean employees have intention to act on these environmental issues. Since NEP pushes people to consider the environment itself and the relationship between human and nature, when employees have stronger environmental beliefs, they have environmental factors and social responsibilities as their core values [57]. According to NEP, employees attribute some social problems to problems of the company's sustainable development [57]. As such, as Muralidharan and Pathak posited, "Followers' perceptions of a leader are embedded in the society's cultural values. These values are outcomes of repeated behaviors that shape the cultural expectations of ideal leadership, and leaders tend to behave in line with these expectations" [27]. Therefore, when the green development idea from green transformational leadership fits employees' environmental beliefs, employees will be more motivated and capable of working on green products. Further, according to TNA, when employees have higher environmental norms, they feel obligated to fulfil leader's expectations [75]. As such, if green transformational leadership advocates green development needs that match employees' green values, employees will continue to strive to maintain this psychological climate to reduce cognitive bias or psychological danger. The related green behavior will help enterprises improve green product development performance. Hence, we posit that when employees' green values and green transformational leadership are fit, green product development performance will increase through green psychological climate.

Hypothesis 8a (H8a). Individual green values will moderate the effects of green transformational leadership and green psychological climate. That is, the effects will be stronger when individual green values are high and vice versa.

Hypothesis $\mathbf{8 b} \mathbf{b} \mathbf{H 8 b})$. Individual green values will moderate the effects of green transformational leadership and green product development performance. That is, the effects will be stronger when individual green values are high and vice versa.

After the logical deduction of the above research hypotheses, this paper proposes the following model, as shown in Figure 1. 


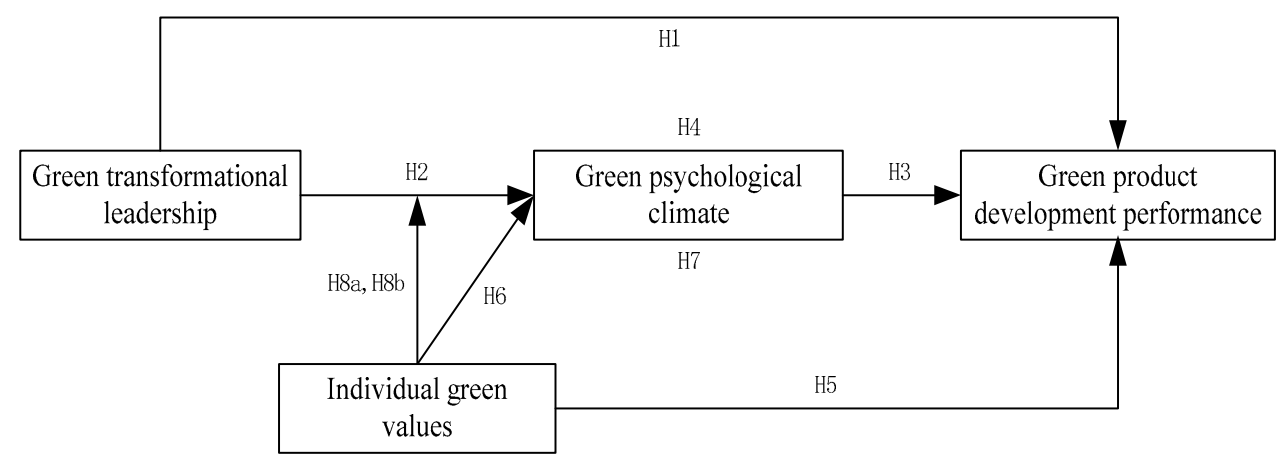

Figure 1. Concept model.

\section{Research Design}

\subsection{Sampling and Data Collection}

For this study, questionnaire data were collected by MBA students, through private relationships, and local government members. This study received 63 sets of responses. A total of 352 questionnaires were distributed, and 307 questionnaires were recovered. Overall, 93 questionnaires were invalid, and 214 questionnaires were sufficiently completed with 52 sets of responses. There was an average of 4.12 employees in each group.

\subsection{Measures}

In this study, standard scales were used that were previously tested for measuring all the constructs (Table 1). The variables of this study were measured on a five point Liker-type scale (1 represented strongly disagree and 5 strongly agree).

\subsubsection{Green Transformational Leadership}

Green transformational leadership was measured using a six-item scale developed by Chen and Chang [6]. They developed a measurement tool for green transformational leadership based on the study of Podsakoff et al. [76]. The Cronbach's alpha coefficient of green transformational leadership was 0.903 . The six measurement items for green transformational leadership were: “The leader of the green product development project inspires project members with the environmental plans", "The leader of the green product development project provides a clear environmental vision for the project members to follow", "The leader of the green product development project enables the project members to work together for the same environmental goals", "The leader of the green product development project encourages the project members to achieve the environmental goals", "The leader of the green product development project acts with considering environmental beliefs of the project members", and "The leader of the green product development project stimulates the project members to think about green ideas".

\subsubsection{Green Psychological Climate}

Green psychological climate was measured using a five-item instrument based on the scale developed and validated by Norton et al. [34]. The Cronbach's alpha coefficient of green psychological climate was 0.920 . The five measurement items for green psychological climate were: "Our company is worried about its environmental impact", "Our company is interested in supporting environmental causes", "Our company believes it is important to protect the environment", "Our company is concerned with becoming more environmentally friendly", and "Our company would like to be seen as environmentally friendly". 


\subsubsection{Green Product Development Performance}

Green product development performance was measured using a five item scale developed by Chen and Chang [6]. They developed a measurement tool for green product development performance based on the study of Marsh and Stock [77]. The Cronbach's alpha coefficient of green product development performance was 0.920 . The five measurement items for green transformational leadership were: "The green product development project contributes a key source of revenues to the company", "The green product development project develops excellent green products", "The green product development project continually improves its development processes over time", "The green product development project is more innovative in green product development than its competitors", and "The green product development project can meet its environmental goals in green product development".

\subsubsection{Individual Green Values}

According to Chou's research, individual green values include both individual environmental beliefs and personal environmental norms [59]. Eight items from the revised NEP [57] were used to examine individual environmental beliefs. Respondents were asked if they agreed that "The earth is like a spaceship with limited room and resources", or on the contrary, "The so-called 'ecological crisis' facing humankind has been greatly exaggerated" and so on. Nine items were used to indicate personal environmental norms [48,58]. For example, "I feel personally obliged to save as much energy as possible," or "I feel morally obliged to save energy, regardless of what others do" and so on.

\subsubsection{Control Variables}

It was suggested that demographic variables influence organizational performance [78]. As a result, we controlled for sex, age, education, tenure, industry, and firm size. 
Table 1. Construct measurement summary: confirmatory factor analysis and scale reliability.

\begin{tabular}{|c|c|c|c|c|}
\hline Variable & Item Description & Standardized Loading & AVE & Cronbach's o \\
\hline \multirow{6}{*}{$\begin{array}{c}\text { Green } \\
\text { transformational } \\
\text { leadership }\end{array}$} & The leader of the green product development project inspires the project members with the environmental plans & 0.87 & \multirow{6}{*}{0.616} & \multirow{6}{*}{0.903} \\
\hline & The leader of the green product development project provides a clear environmental vision for the project members to follow & 0.83 & & \\
\hline & The leader of the green product development project gets the project members to work together for the same environmental goals & 0.76 & & \\
\hline & The leader of the green product development project encourages the project members to achieve the environmental goals & 0.68 & & \\
\hline & The leader of the green product development project acts with considering environmental beliefs of the project members & 0.83 & & \\
\hline & The leader of the green product development project stimulates the project members to think about green ideas & 0.72 & & \\
\hline \multirow{5}{*}{$\begin{array}{l}\text { Green product } \\
\text { development } \\
\text { performance }\end{array}$} & The green product development project contributes a key source of revenues to the company & 0.85 & \multirow{5}{*}{0.604} & \multirow{5}{*}{0.920} \\
\hline & The green product development project develops excellent green products & 0.81 & & \\
\hline & The green product development project continually improves its development processes over time & 0.72 & & \\
\hline & The green product development project is more innovative in green product development than its competitors & 0.67 & & \\
\hline & The green product development project can meet its environmental goals in green product development & 0.82 & & \\
\hline \multirow{5}{*}{$\begin{array}{l}\text { Green psychological } \\
\text { climate }\end{array}$} & Our company is worried about its environmental impact & 0.69 & \multirow{5}{*}{0.577} & \multirow{5}{*}{0.920} \\
\hline & Our company is interested in supporting environmental causes & 0.85 & & \\
\hline & Our company believes it is important to protect the environment & 0.83 & & \\
\hline & Our company is concerned with becoming more environmentally friendly & 0.74 & & \\
\hline & Our company would like to be seen as environmentally friendly & 0.67 & & \\
\hline \multirow{8}{*}{$\begin{array}{l}\text { Environmental } \\
\text { beliefs }\end{array}$} & We are approaching the limit of the number of people the earth can support & 0.81 & \multirow{8}{*}{0.553} & \multirow{8}{*}{0.917} \\
\hline & The earth is like a spaceship with very limited room and resources & 0.73 & & \\
\hline & When humans interfere with nature, it often produces disastrous consequences & 0.85 & & \\
\hline & The balance of nature is very delicate and easily upset & 0.81 & & \\
\hline & Humans have the right to modify the natural environment to suit their needs & 0.74 & & \\
\hline & Humans are severely abusing the environment & 0.67 & & \\
\hline & The so-called "ecological crisis" facing humankind has been greatly exaggerated & 0.62 & & \\
\hline & If things continue on their present course, we will soon experience a major ecological catastrophe & 0.69 & & \\
\hline \multirow{9}{*}{$\begin{array}{l}\text { Environmental } \\
\text { norms }\end{array}$} & I feel personally obliged to save as much energy as possible & 0.76 & \multirow{9}{*}{0.577} & \multirow{9}{*}{0.894} \\
\hline & I feel morally obliged to save energy, regardless of what others do & 0.77 & & \\
\hline & I feel guilty when I waste energy & 0.73 & & \\
\hline & I feel morally obliged to use green instead of regular electricity & 0.64 & & \\
\hline & People like me should do everything they can to reduce energy use & 0.81 & & \\
\hline & If I would buy a new washing machine, I would feel morally obliged to buy an energy efficient one & 0.68 & & \\
\hline & I do not feel guilty at all when I buy vegetables and fruit from distant countries & 0.85 & & \\
\hline & I feel obliged to bear the environment and nature in mind in my daily behavior & 0.81 & & \\
\hline & I would be a better person if I saved energy & 0.76 & & \\
\hline
\end{tabular}




\subsection{Analytic Approach}

\subsubsection{Construct Validity}

We conducted confirmatory factor analyses (CFA) using questionnaire data to test the construct distinctiveness of green transformational leadership, green psychological climate, individual green values, and green product development performance. The four-factor model with all indicators fit the data better $\left(\chi^{2} /\right.$ d.f. $\left.=2.79, \mathrm{RMSEA}=0.04, \mathrm{NFI}=0.95, \mathrm{CFI}=0.94, \mathrm{GFI}=0.91, \mathrm{SRMR}=0.06\right)$ than the three alternative models: a three-factor model in which green transformational leadership and individual green values were distinct, where green psychological climate and green product development performance were combined $\left(\chi^{2} /\right.$ d.f. $=8.56$, RMSEA $=0.22, \mathrm{NFI}=0.86, \mathrm{CFI}=0.90, \mathrm{GFI}=0.73$, SRMR $=0.12$ ); a two-factor model in which green transformational leadership and individual green values were combined, and green psychological climate and green product development performance were combined $\left(\chi^{2} /\right.$ d.f. $=11.13$, RMSEA $=0.27, \mathrm{NFI}=0.91, \mathrm{CFI}=0.88, \mathrm{GFI}=0.72$, SRMR $=0.17$ ); a one-factor model in which green transformational leadership, green psychological climate, individual green values, and green product development performance were combined $\left(\chi^{2} /\right.$ d.f. $\left.=13.71, \mathrm{RMSEA}=0.25, \mathrm{NFI}=0.85, \mathrm{CFI}=0.89, \mathrm{GFI}=0.57, \mathrm{SRMR}=0.18\right)$. In summary, the construct distinctiveness of green transformational leadership, green psychological climate, individual green values, and green product development performance was supported.

\subsubsection{Assessing the Effects of Common Method Variance}

We conducted structural equation modeling (SEM) to assess the potential impact of common method bias on the hypothesized relationships $[79,80]$. We compared Model A, the theoretically hypothesized model, to Model B, a model with two latent common method variance (CMV) factors added to the original theoretically hypothesized model. One of these two extra CMV factors was defined as measures reported by employees (i.e., green transformational leadership and green psychological climate); the other was defined as measures reported by leaders (i.e., green psychological climate and green product development performance), thus capturing any additional systematic method variance common to these measures (e.g., common rate bias, social desirability, yes-saying, etc.) [79]. The SEM analyses results showed that both Model A ( $\chi^{2} /$ d.f. $=2.79, \mathrm{RMSEA}=0.04, \mathrm{NFI}=0.95$, $\mathrm{CFI}=0.94, \mathrm{GFI}=0.91, \mathrm{SRMR}=0.06)$ and Model B yielded a good fit to the data $\left(\chi^{2} /\right.$ d.f. $=3.12$, RMSEA $=0.06$, CFI $=0.92, \mathrm{TLI}=0.93$, SRMR $=0.05$ ). This result suggests that the theoretical model fitted the data reasonably well with and without controlling for the two extra CMV factors. Therefore, common method variance did not substantially influence the hypothesized relationships between the leader behaviors, mediators, and outcome variable.

\section{Results}

\subsection{Data Analysis}

First, a correlation analysis was conducted to test the overall validity of the research model. Then, hierarchical regression analysis was used to test the research hypotheses with all the variables included in this study. All variables, including control variables, were standardized. To test the mediation effects of green psychological climate between green transformational leadership and green product development performance, the following four-step procedure was used [81]: (1) analyzing the significant relationship between green transformational leadership and green product development performance, (2) analyzing the existence of a significant relationship between green transformational leadership and green psychological climate, (3) analyzing whether there is a significant relationship between green psychological climate and green product development performance, and (4) controlling the influence of green psychological climate when determining whether the original relationships between green transformational leadership and green product development performance are reduced 
to no significance or become smaller. Finally, we tested whether individual green values moderate the relationship between green transformational leadership and green product development performance.

\subsection{Hypotheses Test}

\subsubsection{Correlation Analysis}

The correlation analysis of this research is shown in Table 2.

Table 2. Means, standard deviations, and correlations among the core variables.

\begin{tabular}{|c|c|c|c|c|c|c|c|c|c|c|c|c|}
\hline Variable & $\mathbf{M}$ & SD & 1 & 2 & 3 & 4 & 5 & 6 & 7 & 8 & 9 & 10 \\
\hline 1. Sex & 0.56 & 1.07 & 1 & & & & & & & & & \\
\hline 2. Age & 3.12 & 3.22 & $0.127^{*}$ & 1 & & & & & & & & \\
\hline 3. Education & 3.44 & 2.51 & 0.214 & $0.171 *$ & 1 & & & & & & & \\
\hline 4. Tenure & 2.98 & 3.78 & $0.306^{*}$ & 0.163 * & 0.320 & 1 & & & & & & \\
\hline 5. Industry & 3.12 & 1.32 & $0.079 * *$ & 0.239 & 0.291 * & 0.231 & 1 & & & & & \\
\hline 6. Firm size & 2.88 & 0.95 & 0.112 & $0.194^{* *}$ & 0.087 & $0.114^{*}$ & $0.271 * *$ & 1 & & & & \\
\hline 7. GTL & 3.29 & 1.02 & $0.309^{* *}$ & 0.202 & 0.197 & 0.329 & 0.206 & $0.137^{* *}$ & 1 & & & \\
\hline 8. GPC & 3.52 & 0.78 & 0.203 & 0.207 * & $0.191^{* * *}$ & 0.108 & 0.331 * & 0.274 & $0.505^{* *}$ & 1 & & \\
\hline 9. IGV & 3.17 & 0.82 & 0.091 * & 0.176 & 0.084 & $0.137^{* *}$ & 0.019 & $0.056^{*}$ & 0.427 * & 0.312 ** & 1 & \\
\hline 10. GPDP & 3.46 & 0.71 & 0.103 & $0.185^{* * *}$ & $0.156^{*}$ & 0.098 & 0.124 * & 0.102 & $0.277^{* * *}$ & $0.224 * *$ & 0.213 * & 1 \\
\hline
\end{tabular}

Notes: ${ }^{*} p<0.05$ level (2-tailed); ${ }^{* *} p<0.01$ level (2-tailed); $* * * p<0.001$ level (2-tailed). GTL: green transformational leadership; GPC: green psychological climate; IGV: individual green values; GPDP: green product development performance.

From the results, green transformational leadership was significantly correlated with green psychological climate $(r=0.505, p<0.01)$, green transformational leadership was significantly correlated with individual green values $(r=0.427, p<0.05)$, green transformational leadership was significantly correlated with green product development performance $(r=0.277, p<0.001)$, individual green values were significantly correlated with green psychological climate $(r=0.312, p<0.01)$, green psychological climate was significantly correlated with green product development performance $(r=0.224, p<0.01)$, and individual green values were significantly correlated with green product development performance $(r=0.213, p<0.05)$. This result created a good foundation for the subsequent data analysis of this paper.

\subsubsection{Mediation Model Analysis}

Table 3 depicts the hierarchical regression analysis results for the hypothesized mediation model. Models 1 and 2 represented the effects of the control variables on mediator variables and outcome variables. Model 3 showed that green transformational leadership was significantly and positively related to green psychological climate $(\beta=0.211, p<0.01)$. Therefore, $\mathrm{H} 2$ was supported. Model 4 showed that the impact of green transformational leadership on green product development performance was significant and positive $(\beta=0.317, p<0.01)$. Thus, $\mathrm{H} 1$ was supported. Model 5 showed that individual green values were significantly and positively related to green psychological climate $(\beta=0.191, p<0.01)$. Therefore, H6 was supported. Model 6 showed that individual green values were not significantly and positively related to green product development performance $(\beta=0.354, p=$ ns (not significant)). Thus, H5 was not supported. Model 7 showed that green psychological climate was positively associated with green product development performance ( $\beta=0.362, p<0.01)$. Consequently, H3 was supported. Model 8 indicated that when green psychological climate was added into the regression Model 4, the initial significant relationship between green transformational leadership and green product development performance did not disappear but decreased to a moderate level $(\beta=0.237, p<0.05 ; \beta=0.261, p<0.01)$. Consequently, $\mathrm{H} 4$ was supported. The results suggested that green psychological climate partially mediated the relationship between green transformational leadership and green product development performance. Model 9 indicated that when green psychological climate was added into the regression Model 6, the relationship between green psychological climate and green product development performance 
was positively correlated $(\beta=0.243, p<0.01)$, and the relationship between individual green values and green product development performance was also positively correlated ( $\beta=0.217, p<0.05$ ). The results suggested that green psychological climate completely mediated the relationship between individual green values and green product development performance. Thus, H7 was supported.

Table 3. Results for hierarchical regression for mediation tests.

\begin{tabular}{|c|c|c|c|c|c|c|c|c|c|}
\hline Variable & Model 1 & Model 2 & Model 3 & Model 4 & Model 5 & Model 6 & Model 7 & Model 8 & Model 9 \\
\hline & GPC & GPDP & GPC & GPDP & GPC & GPDP & GPDP & GPDP & GPDP \\
\hline \multicolumn{10}{|l|}{ Control } \\
\hline Sex & 0.112 & 0.107 & 0.123 & 0.150 * & 0.117 * & 0.191 & $0.193 *$ & 0.209 & $0.201 *$ \\
\hline Age & 0.213 * & 0.263 & 0.208 * & 0.217 & 0.232 & 0.271 & 0.223 & $0.197 *$ & 0.118 \\
\hline Education & 0.091 & $0.119^{* *}$ & 0.072 & 0.084 & 0.102 * & 0.092 & 0.069 & 0.077 & 0.063 \\
\hline Tenure & -0.072 & -0.102 & -0.054 & $-0.047^{*}$ & -0.052 & $-0.077^{*}$ & -0.086 & -0.092 & -0.082 * \\
\hline Industry & -0.018 & 0.031 & -0.033 & -0.029 & -0.033 & -0.059 & -0.041 & -0.036 & -0.023 \\
\hline Firm size & 0.204 * & 0.121 & 0.213 * & 0.301 & 0.218 & 0.281 & 0.194 & $0.218^{*}$ & 0.161 \\
\hline \multicolumn{10}{|l|}{$\begin{array}{l}\text { Independent } \\
\text { variable }\end{array}$} \\
\hline GTL & & & $0.211^{* *}$ & $0.317^{* *}$ & & & & $0.237^{*}$ & \\
\hline IGV & & & & & $0.191^{* *}$ & 0.254 & & & $0.217^{*}$ \\
\hline \multicolumn{10}{|l|}{$\begin{array}{l}\text { Mediator } \\
\text { variable }\end{array}$} \\
\hline GPC & & & & & & & $0.362^{* *}$ & $0.261^{* *}$ & $0.243^{* *}$ \\
\hline $\mathrm{R}^{2}$ & 0.061 & 0.059 & 0.116 & 0.213 & 0.171 & 0.193 & 0.276 & 0.311 & 0.305 \\
\hline$\Delta \mathrm{R}^{2}$ & $0.053^{* *}$ & $0.047^{* *}$ & $0.107^{* *}$ & $0.211^{* *}$ & $0.165^{* *}$ & $0.187^{* *}$ & $0.254^{* *}$ & $0.309 * *$ & $0.293^{* *}$ \\
\hline
\end{tabular}

Notes: ${ }^{*} p<0.05$ level (2-tailed); ${ }^{* *} p<0.01$ level (2-tailed). GTL: green transformational leadership; GPC: green psychological climate; IGV: individual green values; GPDP: green product development performance.

\subsubsection{Matching Model Analysis}

Table 4 provides the hierarchical regression analysis results for the hypothesized matching model. Model 1 indicated when green transformational leadership and individual green values were added into the regression model, both were positively related to green psychological climate $(\beta=0.297$, $p<0.01 ; \beta=0.115, p<0.05$ ). Model 2 showed that when green transformational leadership, individual green values, and the interaction term between transformational leadership and individual green values were added into the regression Model 2, all three were positively related to green psychological climate, and the role of interaction term was greater than transformational leadership or individual green values. ( $\beta=0.302, p<0.01 ; \beta=0.191, p<0.05 ; \beta=0.397, p<0.001)$. Consequently, H8a was supported. Model 3 indicated when green transformational leadership and individual green values were added into the regression model, both were positively related to green product development performance $(\beta=0.116, p<0.05 ; \beta=0.213, p<0.05$ ). Model 4 showed when green transformational leadership, individual green values, and the interaction term between transformational leadership and individual green values were added into the regression Model 3, all three were positively related to green product development performance, and the role of the interaction term was greater than transformational leadership or individual green values $(\beta=0.123, p<0.05 ; \beta=0.224, p<0.05 ; \beta=0.250$, $p<0.01)$. Consequently, H8b was supported.

To illustrate the interactive patterns for individual green values, we plotted the interactions at one standard deviation above $(+1)$ and below $(-1)$ the mean level of individual green values to make the high and low values fall into their respective region of significance (Figures 2 and 3). As expected, green transformational leadership was positively related to green psychological climate when individual green values were high (simple slope $=0.42, p<0.01$ ). Although green transformational leadership was positively related to green psychological climate when individual green values were low, the simple slope was significantly reduced (simple slope $=0.31, p<0.01$ ). Thus, H8a was supported. Green transformational leadership was positively related to green product development performance when individual green values were high (simple slope $=0.38, p<0.01$ ). Although green transformational leadership was positively related to green product development performance when individual green values were low, the simple slope was significantly reduced (simple slope $=0.29$, $p<0.01)$. Thus, H8b was supported. 
Table 4. Results for hierarchical regression for moderating tests.

\begin{tabular}{ccccc}
\hline Variable & Model 1 & Model 2 & Model 3 & Model 4 \\
\hline Control & GPC & GPC & GPDP & GPDP \\
Sex & & & & \\
Age & $0.201^{*}$ & 0.187 & 0.172 & 0.211 \\
Education & 0.231 & 0.213 & $0.228^{*}$ & 0.179 \\
Tenure & 0.031 & 0.056 & 0.017 & 0.063 \\
Industry & -0.087 & $-0.052^{*}$ & -0.071 & -0.067 \\
Firm size & -0.028 & -0.031 & -0.054 & -0.041 \\
Independent variable & $0.217^{*}$ & 0.321 & 0.162 & $0.196^{*}$ \\
GTL & $0.297^{* *}$ & $0.302^{* *}$ & $0.116^{*}$ & $0.123^{*}$ \\
Moderating variable & & & & \\
IGV & $0.115^{*}$ & $0.191^{*}$ & $0.213^{*}$ & $0.224^{*}$ \\
Interaction & & & & $0.250^{* *}$ \\
GTL IGV & & $0.397^{* * *}$ & & 0.197 \\
$\mathrm{R}^{2}$ & 0.113 & 0.224 & 0.233 & $0.182^{* *}$ \\
$\Delta \mathrm{R}^{2}$ & $0.101^{* *}$ & $0.218^{* *}$ & $0.209^{* *}$ &
\end{tabular}

Notes: ${ }^{*} p<0.05$ level (2-tailed); ${ }^{* *} p<0.01$ level (2-tailed); ${ }^{* *} p<0.001$ level (2-tailed). GTL: green transformational leadership; GPC: green psychological climate; IGV: individual green values; GPDP: green product development performance.

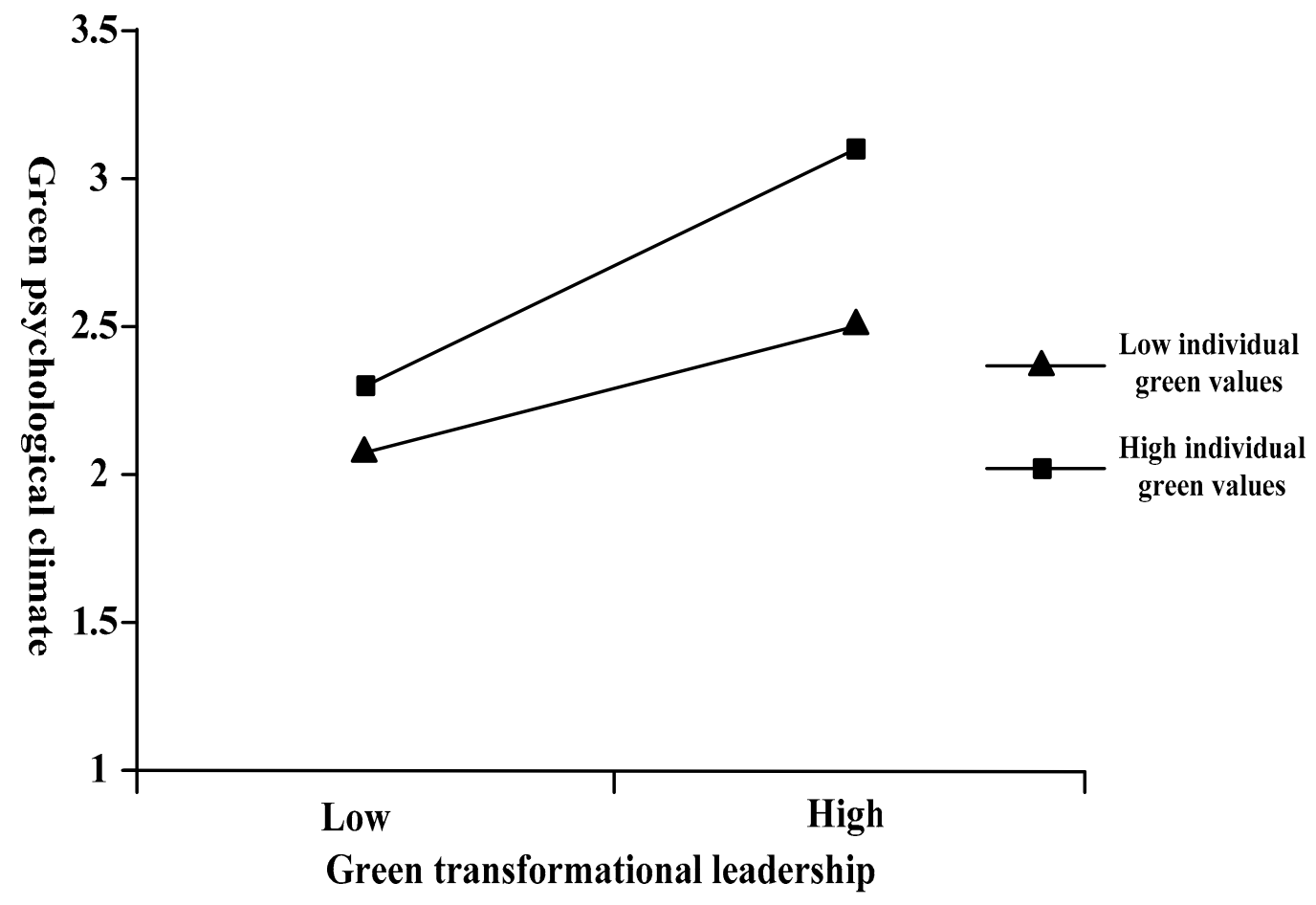

Figure 2. The interaction between green transformational leadership and individual green values on green psychological climate. 


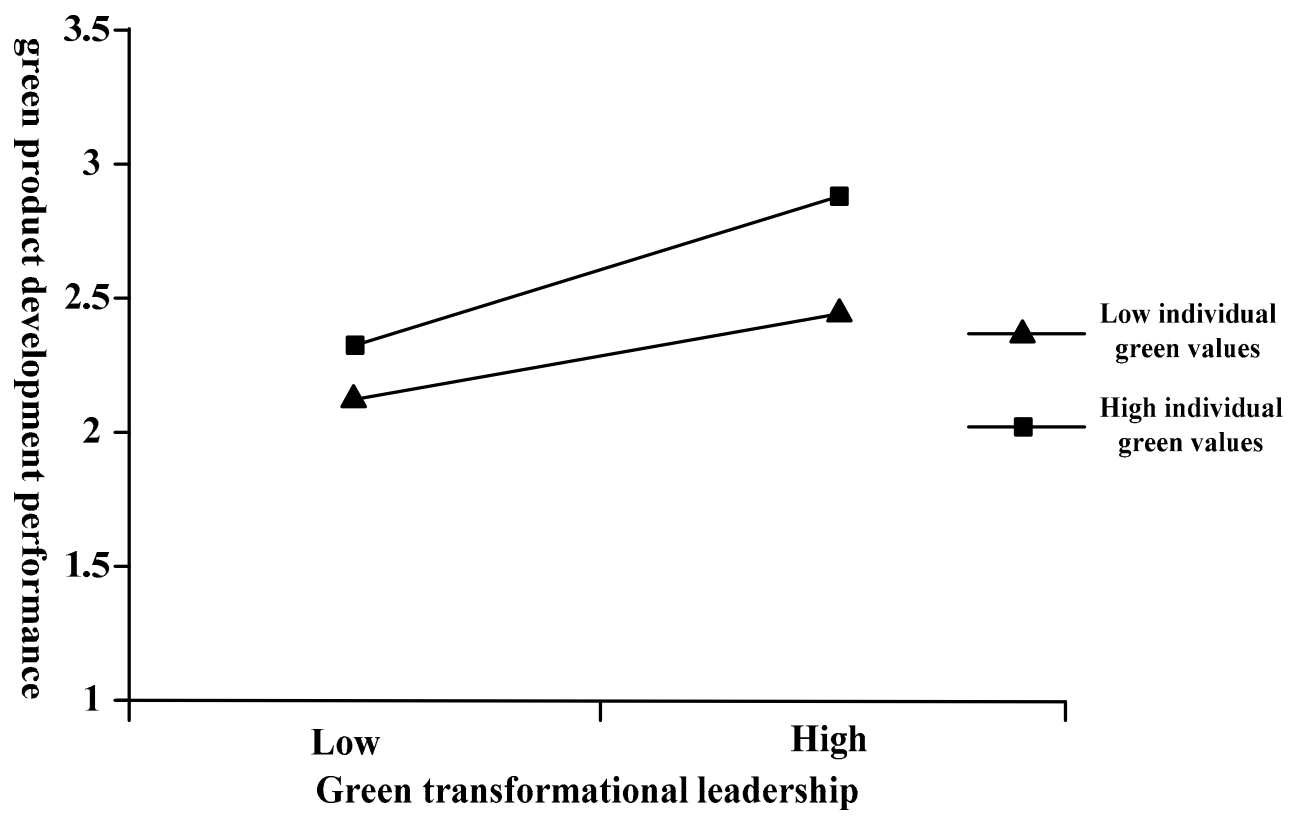

Figure 3. The interaction between green transformational leadership and individual green values on green product development performance.

\section{Conclusions}

Based on the above hypothesis test, the conclusions of this paper are provided in Table 5 .

Table 5. Results of hypothesis tests.

\begin{tabular}{clc}
\hline No. & \multicolumn{1}{c}{ Hypothesis } & Result \\
\hline H1 & $\begin{array}{l}\text { Green transformational leadership is positively related to green product development } \\
\text { performance. }\end{array}$ & Support \\
\hline H1 & Green transformational leadership is positively related to green psychological climate. & Support \\
\hline H3 & $\begin{array}{l}\text { Green psychological climate is positively related to green product development } \\
\text { performance. }\end{array}$ & Support \\
\hline H4 & $\begin{array}{l}\text { Green psychological climate mediates the relationship between green transformational } \\
\text { leadership and green product development performance. }\end{array}$ & Support \\
\hline H5 & Individual green values are positively related to green product development performance. & Not Supported \\
\hline H6 & Individual green values are positively related to green psychological climate. & Support \\
\hline H7 & $\begin{array}{l}\text { Individual green values mediate the relationship between individual green values and } \\
\text { green product development performance. }\end{array}$ & Support \\
\hline H8a & $\begin{array}{l}\text { Individual green values will moderate the effects of green transformational leadership and } \\
\text { green psychological climate. That is, the effects will be stronger when individual green } \\
\text { values are high and vice versa. }\end{array}$ & Support \\
\hline H8b & $\begin{array}{l}\text { Individual green values will moderate the effects of green transformational leadership and } \\
\text { green product development performance. That is, the effects will be stronger when } \\
\text { individual green values are high and vice versa. }\end{array}$ & Support \\
\hline
\end{tabular}

Based on the results above, we found that $\mathrm{H} 1$ was verified. In fact, in the field of management psychology, leadership has become a hot research point. As a product of sustainable development, green transformational leadership cannot be ignored in increasing the company's green product development performance. Green transformational leadership provides employees with material and spiritual support, and actively creates a positive green psychological climate in the organization, which helps improve the organization's green product development performance.

Additionally, the results of the data analysis showed that $\mathrm{H} 2, \mathrm{H} 3$, and $\mathrm{H} 4$ were verified. This indicates that the employee green psychological climate plays a mediating role in green 
transformational leadership and green product development performance. After receiving material and spiritual support from leaders, the positive green psychological climate generated by employees motivates them to engage in work, generate green behaviors, and feel that they themselves have the responsibility to increase the green product development performance that the organization expects. Also, H6 was verified, which explains that individual green values are positively related to green psychological climate. These conclusions prove that not only the technical level, but also the employee psychological level affect the green product performance of the enterprise. At the same time, H7 was verified, whereas $\mathrm{H} 5$ was not. This indicates that green psychological climate plays a complete mediating role between individual green values and green product development performance. At the same time, the matching effect of green transformational leadership and individual green values to green psychological climate was greater than the effects that they respectively have on green psychological climate. This further demonstrates that the exploration of green product development issues should not only be discussed from a unilateral perspective of employees or leaders. Individual green values also need support from the organization and the matching of leaders. Only when leaders and employees are in a "mind acts upon mind" state in terms of green development concepts and create a high-intensity organizational climate, will the promotion effects on green product development performance be revealed.

Finally, the results of the data analysis indicated that $\mathrm{H} 8 \mathrm{a}$ and $\mathrm{H} 8 \mathrm{~b}$ were validated. This shows that when there is a match between green transformation leadership and employee green psychological climate, the organization's green product development performance is improved. When employees have strong environmental beliefs and environmental norms, employees have a strong sense of environmental protection, which meets the green development expectations advocated by green transformation leaders. In order to maintain this matching relationship, the two factors continue to create a high-intensity green psychological climate through technical support, concept exchange, etc., thereby enhancing the organization's green product development performance.

\subsection{Theoretical Implications}

This study contributes to the literature in several aspects. First, green transformational leadership has both a direct and indirect effect on green product development performance. This conclusion confirms the important role of leaders in the process of green product development. Prior studies mainly focused on the corporation itself or employees when researching green product development, including the impact of green dynamic capabilities [6], green development strategies [36], employees' technical capabilities [9], and their creativity [6,18]. However, the leader, as the forerunner of organizational strategy and the pioneer of organizational management, is bound to affect the product development performance in the company, including stimulating employees' motivation [22,24] and satisfying their psychological needs $[21,23]$. In the present research area of green product development, the role of leaders has not received much attention by scholars. Therefore, this paper focused on green transformational leadership, which shifts the focus of leadership in the research of green product development. Besides, the values of green transformational leadership coincide with the culture of social development. As a kind of culturally endorsed transformational leadership, this study responded to the call by Muralidharan and Pathak [27] to examine the importance of culturally endorsed transformational leadership theories in the field of social sustainable development.

Second, though employees' green psychological climate, green transformational leadership, and individual green values ultimately affect green product development performance, this conclusion confirms the important role of psychological factors in green product development performance in enterprises $[15,16]$. Prior literature reported divergent conclusions on the role of human and organizational aspects in promoting green product development in enterprises [9]. Through empirical tests, this paper proved that the human aspect-the psychological aspect-is positively related to green product development performance. On one hand, this study clarified the relationship between human aspects and organizational performance in the field of sustainable development; on the other, 
this study introduced management psychology to the research area of green product development and created a bridge between the research field of sustainable development and management psychology.

Third, the matching of green transformational leadership and employees' green values affects the green psychological climate and green product development performance. This conclusion emphasizes the important role of the matching mechanism between employee values and leadership styles. In the past, only Chen and Chang explored the impact of green transformational leadership on green product development performance [6]. However, in the field of human resource management, good interactions between leaders and employees are the key to achieving sustainable development $[13,70,71]$. Therefore, based on the person-supervisor fit theory [72], we found that when green transformational leadership matches employees' individual values, it can create a high-level psychological climate. This study extended the application of person-supervisor fit theory from the area of human resource management to sustainable development.

Finally, scholars have different opinions on the definition and scope of individual green values, whether focusing on environmental beliefs [57] or environmental norms [48,58]. On the basis of Chou's research [59], we combined the two aspect of environmental belief and environmental norms to more accurately and comprehensively describe individual green values. This will further enrich theoretical and practical research on individual green values.

\subsection{Practical Implications}

The findings of this study provide crucial suggestions for different companies in dealing with sustainable development problems.

First, as the leading figure in the organization, leaders have an important impact on the formulation of organizational strategy, the production of green products and employee psychology. Through the conclusion of this study, we found that green transformational leadership can positively affect employees' green psychological climate, thereby enhancing green product development performance. At the organizational level, this conclusion guides enterprises in the process of creating and implementing green development strategy and developing green products. It is important to pay more attention to the role of leaders and promote their leading position in the development of green products. At the individual level, this conclusion informs the leaders themselves to have green development awareness, learn the characteristics from green transformational leaders, and pay more attention to environmental protection and sustainable development of enterprises.

Second, individual psychological climate plays an important role in product development and organizational performance improvement. According to the conclusions of this study, the green psychological climate not only plays a mediating role between green transformational leadership and green product development performance, but also mediates individual green values and green product development performance. This conclusion suggests that corporations and managers should consider technology, capability, and innovation, in the process of improving the organizational green products performance, as well as think about the factors involved in the psychological aspects. Enterprises can create green development policies, adopt green management practices, establish green management procedures, and also actively promote green development ideals, to establish a high-intensity green psychological climate.

Finally, individual values are also vital in organizational development. Through this research, we found that the matching of individual green values and green transformational leadership positively impacts employees' green psychological climate and organizational green product development performance. This conclusion indicates that enterprises can recruit employees with green values to achieve the "mind acts upon mind" of employees and leaders. They can also continuously strengthen employees' green values and enhance their social responsibility by instilling environmental protection concepts in their daily work, including enhancing both their environmental beliefs and environmental norms. At the same time, leaders should also strive to maintain a balance of value matching with 
employees, for example, by providing technical support and communicating environmental ideas with employees.

\section{Research Limitations and Future Research Directions}

There are some limitations to this study. First, the analysis of this study was not conducted in different industries. There is a difference in the awareness of environmental protection issues in different industries. In the future, studies should be conducted by analyzing companies with different backgrounds. Second, although this study focused on the matching role of individual values, we did not account for the effects of corporate culture and social culture. Corporate culture can not only affect the awareness of enterprises, leaders, and employees, but may also impact the development of ideals and leadership and employee green values. Therefore, future studies can consider cultural factors. Third, in future studies, more control variables can be considered, such as government policy.

Author Contributions: S.Z. and D.Z. conceived and designed the experiments; S.Z. and D.Z. performed the experiments; D.Z. and C.L. analyzed the data; C.L. contributed reagents/materials/analysis tools; S.Z. and D.Z. wrote the paper; H.Z. supported the research.

Funding: The Fundamental Research Funds for the Central Universities (N170606002). The Natural Science Foundation of China (71672029) and Macao Polytechnic Institute (RP/OTHER-01/2017).

Acknowledgments: We would like to thank The Fundamental Research Funds for the Central Universities (N170606002), The Natural Science Foundation of China (71672029) and Macao Polytechnic Institute (RP/OTHER-01/2017) for the financial support of the research project.

Conflicts of Interest: The authors declare no conflict of interest.

\section{References}

1. Alt, E.; Spitzeck, H. Improving environmental performance through unit-level organizational citizenship behaviors for the environment: A capability perspective. J. Environ. Manag. 2016, 182, 48-58. [CrossRef] [PubMed]

2. Roy, M.; Khastagir, D. Exploring role of green management in enhancing organizational efficiency in petro-chemical industry in India. J. Clean. Prod. 2016, 121, 109-115. [CrossRef]

3. Mittal, S.; Dhar, R.L. Effect of green transformational leadership on green creativity: A study of tourist hotels. Tour. Manag. 2016, 57, 18-127. [CrossRef]

4. Song, W.; Yu, H. Green innovation strategy and green innovation: The roles of green creativity and green organizational identity. Corp. Soc. Responsib. Environ. Manag. 2018, 25, 135-150. [CrossRef]

5. Neubaum, D.O.; Dibrell, C.; Craig, J.B. Balancing natural environmental concerns of internal and external stakeholders in family and non-family businesses. J. Fam. Bus. Strategy 2012, 3, 28-37. [CrossRef]

6. Chen, Y.S.; Chang, C.H. The determinants of green product development performance: Green dynamic; capabilities, green transformational leadership, and green creativity. J. Bus. Ethics 2013, 116, 107-119. [CrossRef]

7. Xie, C.; Bagozzi, R.P.; Grønhaug, K. The role of moral emotions and individual differences in consumer responses to corporate green and non-green actions. J. Acad. Mark. Sci. 2015, 43, 333-356. [CrossRef]

8. Fraj, E.; Matute, J.; Melero, I. Environmental strategies and organizational competitiveness in the hotel industry: The role of learning and innovation as determinants of environmental success. Tour. Manag. 2015, 46, 30-42. [CrossRef]

9. Jabbour, C.J.C.; Jugend, D.; Gunasekaran, A.; Angappa, G.; Hengky, L. Green product development and performance of Brazilian firms: Measuring the role of human and technical aspects. J. Clean. Prod. 2015, 87, 442-451. [CrossRef]

10. Chen, Y.S. The driver of green innovation and green image-Green core competence. J. Bus. Ethics 2008, 81, 531-543. [CrossRef]

11. Pujari, D.; Wright, G.; Peattie, K. Green and competitive: Influences on environmental new product development performance. J. Bus. Res. 2003, 56, 657-671. [CrossRef]

12. Lymperopoulos, C.; Chaniotakis, I.E.; Soureli, M. A model of green bank marketing. J. Financ. Serv. Mark. 2012, 17, 177-186. [CrossRef] 
13. Caplan, R.D. Person-environment fit theory and organizations: Commensurate dimensions, time perspectives, and mechanisms. J. Vocat. Behav. 1987, 31, 248-267. [CrossRef]

14. Kim, T.Y.; Liden, R.C.; Kim, S.P.; Deog-Ro, L. The interplay between follower core self-evaluation and transformational leadership: Effects on employee outcomes. J. Bus. Psychol. 2015, 30, 345-355. [CrossRef]

15. Zientara, P.; Zamojska, A. Green organizational climates and employee pro-environmental behaviour in the hotel industry. J. Sustain. Tour. 2016, 1, 1-18. [CrossRef]

16. Milliman, J. Leading-edge green human resource practices: Vital components to advancing environmental sustainability. Environ. Qual. Manag. 2014, 23, 31-45. [CrossRef]

17. Guest, D.W.; Teplitzky, A.L. High-performance environmental management systems: Lessons learned from 250 visits at leadership facilities. Environ. Qual. Manag. 2010, 20, 25-38. [CrossRef]

18. Robinson, D.; Clegg, A. Environmental leadership and competitive advantage through environmental management system standards. Eco-Manag. Audit. 2010, 5, 6-14. [CrossRef]

19. Boehm, S.A.; Dwertmann, D.J.; Bruch, H.; Shamir, B. The missing link? Investigating organizational identity strength and transformational leadership climate as mechanisms that connect CEO charisma with firm performance. Leadersh. Q. 2015, 26, 156-171. [CrossRef]

20. Pasha, O.; Poister, T.H.; Wright, B.E.; Thomas, J.C. Transformational leadership and mission valence of employees: The varying effects by organizational level. Public Perform. Manag. Rev. 2017, 40, 722-740. [CrossRef]

21. Thomas, W.H. Transformational leadership and performance outcomes: Analyses of multiple mediation pathways. Leadersh. Q. 2017, 28, 385-417.

22. Sethibe, T.G. Towards a comprehensive model on the relationship between leadership styles, organisational climate, innovation and organisational performance. Int. J. Innov. Manag. 2018, 22, 1850021. [CrossRef]

23. Bass, B.M. Transformational Leadership: Industrial, Military, and Educational Impact; Lawrence Erlbaum Associates: Mahwah, NJ, USA, 1998.

24. Robertson, J.L. The nature, measurement and nomological network of environmentally specific transformational leadership. J. Bus. Ethics 2017, 5, 1-15. [CrossRef]

25. Muralidharan, E.; Pathak, S. Sustainability, transformational leadership and social entrepreneurship. Sustainability 2018, 10, 567. [CrossRef]

26. Gabler, C.B.; Richey, R.G., Jr.; Rapp, A. Developing an eco-capability through environmental orientation and organizational innovativeness. Ind. Mark. Manag. 2015, 45, 151-161. [CrossRef]

27. Chen, T.; Li, F.; Leung, K. When does supervisor support encourage innovative behavior? Opposite moderating effects of general self-efficacy and internal locus of control. Pers. Psychol. 2016, 69, 129-158. [CrossRef]

28. Nohe, C.; Hertel, G. Transformational leadership and organizational citizenship behavior: A meta-analytic test of underlying mechanisms. Front. Psychol. 2017, 8, 1364. [CrossRef] [PubMed]

29. Hay, R. The relevance of ecocentrism, personal development and transformational leadership to sustainability and identity. Sustain. Dev. 2010, 18, 163-171. [CrossRef]

30. Chen, Y.S.; Chang, C.H.; Lin, Y.H. Green transformational leadership and green performance: The mediation effects of green mindfulness and green self-efficacy. Sustainability 2014, 6, 6604-6621. [CrossRef]

31. Goffin, K. Sustainability and new product development. In Cranfield on Corporate Sustainability; Routledge: Abingdon, UK, 2012; pp. 105-118.

32. Rubera, G.; Chandrasekaran, D.; Ordanini, A. Open innovation, product portfolio innovativeness and firm performance: The dual role of new product development capabilities. J. Acad. Mark. Sci. 2016, 44, 166-184. [CrossRef]

33. Li, X.B.; Stephen, J.F.; Sanders, K. Strategic HRM as process: How HR system and organizational climate strength influence Chinese employee attitudes. Int. J. Hum. Resour. Manag. 2011, 22, 1825-1842. [CrossRef]

34. Norton, T.A.; Zacher, H.; Ashkanasy, N.M. Organisational sustainability policies and employee green behaviour: The mediating role of work climate perceptions. J. Environ. Psychol. 2014, 38, 49-54. [CrossRef]

35. Kang, J.H.; Matusik, J.G.; Kim, T.Y. Interactive effects of multiple organizational climates on employee innovative behavior in entrepreneurial firms: A cross-level investigation. J. Bus. Ventur. 2016, 31, 628-642. [CrossRef]

36. Norton, T.A.; Zacher, H.; Parker, S.L. Bridging the gap between green behavioral intentions and employee green behavior: The role of green psychological climate. J. Organ. Behav. 2017, 38, 996-1015. [CrossRef] 
37. Kranabetter, C.; Niessen, C. Managers as role models for health: Moderators of the relationship of transformational leadership with employee exhaustion and cynicism. J. Occup. Health Psychol. 2017, 22, 492-502. [CrossRef] [PubMed]

38. Zhang, Y.; Zheng, J.; Darko, A. How does transformational leadership promote innovation in construction? The mediating role of innovation climate and the multilevel moderation role of project requirements. Sustainability 2018, 10, 1506. [CrossRef]

39. Friedkin, N.E. A structural theory of social influence. Am. J. Sociol. 1998, 45, 162.

40. Maton, K.I. Social support, organizational characteristics, psychological well-being, and group appraisal in three self-help group populations. Am. J. Community Psychol. 1988, 16, 53-77. [CrossRef] [PubMed]

41. Farmer, S.M.; Dyne, L.V. Organization-specific prosocial helping identity: Doing and belonging as the basis of "being fully there". J. Organ. Behav. 2017, 38, 769-791. [CrossRef]

42. Parker, C.P.; Baltes, B.B.; Young, S.A. Relationships between psychological climate perceptions and work outcomes: A meta-analytic review. J. Organ. Behav. 2003, 24, 389-416. [CrossRef]

43. Schrock, W.A.; Hughes, D.E.; Fu, F.Q. Better together: Trait competitiveness and competitive psychological climate as antecedents of salesperson organizational commitment and sales performance. Mark. Lett. 2016, 27, 351-360. [CrossRef]

44. Murillo-Luna, J.L.; Garcés-Ayerbe, C.; Rivera-Torres, P. Barriers to the adoption of proactive environmental strategies. J. Clean. Prod. 2011, 19, 1417-1425. [CrossRef]

45. Delgado-Ceballos, J.; Aragón-Correa, J.A.; Ortiz-De-Mandojana, N. The effect of internal barriers on the connection between stakeholder integration and proactive environmental strategies. J. Bus. Ethics 2012, 107, 281-293. [CrossRef]

46. Seroka-Stolka, O.; Lukomska-Szarek, J. Barriers to the adoption of proactive environmental strategies in polish companies. In Proceedings of the International Academic Conference, Lisbon, Portugal, 22-25 March 2016.

47. Manika, D.; Wells, V.K.; Gregory-Smith, D.; Gentry, M. The impact of individual attitudinal and organisational variables on workplace environmentally friendly behaviours. J. Bus. Ethics 2015, 126, 663-684. [CrossRef]

48. Dumont, J.; Shen, J.; Deng, X. Effects of green HRM practices on employee workplace green behavior: The role of psychological green climate and employee green values. Hum. Resour. Manag. 2017, 56, 613-627. [CrossRef]

49. Day, D.V.; Bedeian, A.G. Predicting job performance across organizations: The interaction of work orientation and psychological climate. J. Manag. 1991, 17, 589-600. [CrossRef]

50. Steers, R.M. Antecedents and outcomes of organizational commitment. Adm. Sci. Q. 1977, 22, 46-56. [CrossRef] [PubMed]

51. Kristofbrown, A.L.; Zimmerman, R.D.; Johnson, E.C. Consequences of individuals' fit at work: A meta-analysis of person-job, person-organization, person-group, and person-supervisor fit. Pers. Psychol. 2005, 58, 281-342. [CrossRef]

52. Orabi, T.G.A. The impact of transformational leadership style on organizational performance: Evidence from Jordan. Int. J. Hum. Resour. Stud. 2016, 6, 2162-3058. [CrossRef]

53. Yasir, M.; Imran, R.; Irshad, M.K. Mediating role of organizational climate in the relationship between transformational leadership, its facets and organizational performance. Actual Probl. Econ. 2013, 7, 559-569.

54. Low, K.C.P. Value matters or do values really make a difference! Educ. Res. 2013, 4, 330-339.

55. Dunlap, R.E.; Van Liere, K.D. The "new environmental paradigm": A proposed measuring instrument and preliminary results. J. Environ. Educ. 1978, 9, 10-19. [CrossRef]

56. Stern, P.C.; Dietz, T.; Guagnano, G.A. Values, beliefs, and proenvironmental action: Attitude formation toward emergent attitude objects. J. Appl. Soc. Psychol. 1995, 25, 1611-1636. [CrossRef]

57. Dunlap, R.E.; Van Liere, K.D.; Mertig, A.G. Measuring endorsement of the new ecological paradigm: A revised NEP scale. J. Soc. Issues 2000, 56, 425-442. [CrossRef]

58. Steg, L.; Dreijerink, L.; Abrahamse, W. Factors influencing the acceptability of energy policies: A test of VBN theory. J. Environ. Psychol. 2005, 25, 415-425. [CrossRef]

59. Chou, C.J. Hotels' environmental policies and employee personal environmental beliefs: Interactions and outcomes. Tourism Manag. 2014, 40, 436-446. [CrossRef]

60. Super, D.E. The Work Values Inventory. J. Vocat. Behav. 1973. [CrossRef]

61. Pryor, R. In search of a concept: Work values. Career Dev. Q. 1979, 27, 250-258. [CrossRef] 
62. William, B.; Swann, J.; Stephen, J.R. Self-verification processes: How we sustain our self-conceptions. J. Exp. Soc. Psychol. 1981, 17, 351-372.

63. Yeh, Y. The effect of organizational culture on career planning and its impact to work motivation and employees performance. Int. J. Manag. Sci. Bus. Res. 2016, 3, 35-47.

64. Kaygin, E.; Gulluce, A.C. The relationship between career choice and individual values: A case study of a Turkish university. Int. J. Hum. Soc. Sci. 2013, 3, 119-134.

65. Friedlander, F.; Margulies, N. Multiple impacts of organizational climate and individual value systems upon job satisfaction. Pers. Psychol. 1969, 22, 171-183. [CrossRef]

66. Milliman, J.; Gatling, A.; Bradleygeist, J.C. The implications of workplace spirituality for person-environment fit theory. Psychol. Relig. Spiritual. 2017, 9, 1-12. [CrossRef]

67. Kozlowski, S.W.J.; Klein, K.J. A multilevel approach to theory and research in organizations: Contextual, temporal, and emergent processes. In Multilevel Theory, Research, E Methods in Organizations: Foundations, Extensions, E New Directions; Jossey-Bass: San Francisco, CA, USA, 2000; pp. 3-90.

68. Schneider, B. The people make the place. Pers. Psychol. 1987, 40, 437-453. [CrossRef]

69. Robbins, M.A. Complimentary ministry? The psychological type of clergy women in the church in wales. Psychology 2015, 6, 1951-1956. [CrossRef]

70. Edwards, J.R. An examination of competing versions of the person-environment fit approach to stress. Acad. Manag. J. 1996, 39, 292-339.

71. Edwards, J.R.; Shipp, A.J. The Relationship between Person-Environment Fit and Outcomes: An Integrative Theoretical Framework; Lawrence Erlbaum Associates Publishers: Mahwah, NJ, USA, 2007; pp. 209-258.

72. Krishnan, V.R. Transformational leadership and value system congruence. Int. J. Value-Based Manag. 2002, 15, 19-33. [CrossRef]

73. Hui, C.H.; Cheng, K.; Gan, Y. Psychological collectivism as a moderator of the impact of supervisor-Subordinate personality similarity on employees' service quality. Appl. Psychol. 2003, 52, 175-192. [CrossRef]

74. Colbert, A.E.; Kristof-Brown, A.L.; Bradley, B.H. CEO transformational leadership: The role of goal importance congruence in top management teams. Acad. Manag. J. 2008, 51, 81-96. [CrossRef]

75. Stern, P.C.; Dietz, T.; Abel, T. A value-belief-norm theory of support for social movements: The case of environmentalism. Hum. Ecol. Rev. 1999, 6, 81-97.

76. Podsakoff, P.M.; Mackenzie, S.B.; Bommer, W.H. Transformational leader behaviors and substitutes for leadership as determinants of employee satisfaction, commitment, trust, and organizational citizenship behaviors. J. Manag. 1996, 22, 259-298. [CrossRef]

77. Marsh, S.J.; Stock, G.N. creating dynamic capability: The role of intertemporal integration, knowledge retention, and interpretation. J. Prod. Innov. Manag. 2006, 23, 422-436. [CrossRef]

78. Salajegheh, S.; Chamanifard, R.; Chamanifard, S. The relationship between quality of work life and organizational performance: The moderating role of demographic variables (a case study of foreign exchange units of Tejarat bank, Iran). Asian J. Res. Bus. Econ. Manag. 2015, 5, 128-141. [CrossRef]

79. Chang, S.J.; Van Witteloostuijn, A.; Eden, L. From the Editors: Commonmethod variance in international business research. J. Int. Bus. Stud. 2010, 41, 178-184. [CrossRef]

80. Podsakoff, P.; MacKenzie, S.; Lee, J.; Podsakoff, N. Common method biases in behavioral research: A critical review of the literature and recommendation remedies. J. Appl. Psychol. 2003, 88, 879-903. [CrossRef] [PubMed]

81. Baron, R.M.; Kenny, D.A. The moderator-mediator variable distinction in social psychological research: Conceptual, strategic, and statistical considerations. J. Personal. Soc. Psychol. 1986, 51, 1173-1182. [CrossRef]

(C) 2018 by the authors. Licensee MDPI, Basel, Switzerland. This article is an open access article distributed under the terms and conditions of the Creative Commons Attribution (CC BY) license (http:/ / creativecommons.org/licenses/by/4.0/). 